\title{
Evaluation of antibacterial and toxicity activity in vitro of extracts from Tournefortia bicolor S.W (Boraginaceae)
}

\author{
Isabelle Souza de Mélo Silva ${ }^{1}$, Andressa Letícia Lopes da Silva², Raíssa Fernanda Evangelista Pires dos Santos², \\ Renata Rego de Souza ${ }^{1 *}$, Andriele Mendonça Barbosa ${ }^{1}$, Klebson Silva Santos', Mariene Ribeiro Amorim', \\ Lenilson Santos da Trindade ${ }^{1}$, Laiza Canielas Krause ${ }^{1}$, Eliane Aparecida Campesatto ${ }^{3}$, Francine Ferreira Padilha', \\ Maria Lysete de Assis Bastos ${ }^{2}$
}

From 5th Congress of the Brazilian Biotechnology Society (SBBIOTEC)

Florianópolis, Brazil. 10-14 November 2013

\section{Background}

The reported use of medicinal plants has shown that they are part of human evolution and were the first therapeutic resources used by people. The search for new alternatives to replace or serve as an adjunct to antimicrobial treatment available has been prioritized. Brazil has a great biodiversity of plants, which are popularly used for medicinal form. Vegetables have been widely used in health care due to its medicinal properties, such as antibacterial, antifungal and immunomodulatory activities [1], but can be evaluated for their antitumor potential, insecticide, pesticide, or even cercaricide among other biological actions that depend on cytotoxicity $[2,3]$. The aim of this study was to evaluate the in vitro antibacterial activity of the extract, fractions and subfractions of a native plant to the state of Alagoas, the Tournefortia bicolor.

\section{Methods}

Experimental in vitro study, conducted at the Research Laboratory of Wound Care, at Federal University of Alagoas. Three samples were tested at T. bicolor (Sheet Part - Neutral hexane; Stem Part - Acetate fraction; Stem Part - Chloroform fraction and methanol fraction). The samples were subjected to bioassays in Petri dishes by the disk diffusion method to evaluate the potential for bacterial growth inhibition by halo formation facing the strains of Staphylococcus aureus ATCC

'Instituto de Tecnologia e Pesquisa, Universidade Tiradentes - Av. Murilo Dantas, 300, Farolândia - Aracaju, Sergipe, CEP 49032-490, Brazil Full list of author information is available at the end of the article
25923, Klebsiella pneumoniae ATCC 31488, Shigella flexneri ATCC 12022, Enteroccocus faecalis ATCC 29212, Salmonella typhimurium ATCC 14028, Escherichia coli ATCC 14942, Pseudomonas aeruginosa ATCC 27853 and Streptococcus pyogenes ATCC 12344, distributed by the American Type Cell Collection. All extracts were tested against Brine Shrimps.

\section{Results and conclusions}

All samples suggested inactive against the strains tested, due to non-appearance of inhibition zone. Thus, due to inactivity of the samples in the disk diffusion test front of the strains bacterial tested, did not occur to testing of Minimum Inhibitory Concentration (MIC). The cytotoxicity avaliation of the samples was performed using the lethality assay against Brine Shrimps. The extracts evaluated, two had - if nontoxic. In toxicity tests with brine, only the hexane extract neutral - and leaf ethyl acetate - stems were presented nontoxic, with a mortality rate of $0 \%$ and $10 \%$, respectively. The chloroform methanol extract - stem proved toxic with a mortality rate of $73.34 \%$. All extracts were thymol as a positive control, which has the ability to break the cytoplasmic membrane and therefore carry the larvae of Brine Shrimps to death by dehydration [4], with $100 \%$ mortality in the brine. However extracts and pure compounds from plant species that have $\mathrm{CL}_{50}<500 \mathrm{mg} / \mathrm{mL}$ are considered toxic, but can be evaluated for their antitumor potential, insecticide, pesticide, or even cercaricide to combat the infectious form of Schistosoma mansoni among other biological actions that depend on cytotoxicity [2,3]. Studies 
conducted at the National Cancer Institute in the United States, Brine correlated to high toxicity, or $\mathrm{CL}_{50}$ low concentrations with significant growth inhibition in vitro of cell lines derived from solid tumors [5].

\section{Acknowledgements}

Brazilian Ministry of Science and Technology, Federal University of Alagoas, Center for Information Technology (NIT-PROPEP), Research Laboratory of Wound Care, Laboratory of Biomaterials, University Tiradentes.

\section{Authors' details}

${ }^{1}$ Instituto de Tecnologia e Pesquisa, Universidade Tiradentes - Av. Murilo Dantas, 300, Farolândia - Aracaju, Sergipe, CEP 49032-490, Brazil. ²aboratório de Pesquisa em Tratamento de Feridas, Universidade Federal de Alagoas, Campus A. C. Simões - Av. Lourival Melo Mota, s/n, Cidade Universitária Maceió, Alagoas, CEP 57072-900, Brazil. 32Laboratório de Farmacologia e Imunidade, Universidade Federal de Alagoas, Campus A. C. Simões - Av. Lourival Melo Mota, s/n, Cidade Universitária - Maceió, Alagoas, CEP 57072900, Brazil.

Published: 1 October 2014

\section{References}

1. Balbino CA, Pereira LM, Curi R: Mechanisms involved in wound healing: a review. Brazilian Journal of Pharmaceutical Sciences 2005, 41(1):27-51.

2. Mclaughlin JL: Methods in Plant Biochemestry. New York: Academic Press; Dey PM, Harbone J 1991:6:1-32.

3. Solis PN, Wright CW, Anderson MM, Gupta MP, Phillipson D: A microwell cytotoxicity using Artemia salina (Brine shrimp). Planta Med 1992, 59:250-252.

4. Ellis MD, Baxendale FP: Toxicity of seven monoterpenoids to tracheal mites (Acari: Tarsonemidae) and their honey bee (Hymenoptera: Apidae) hosts when applied as fumigants. J Economic Entomology 1997, 90:1087-1091.

5. Anderson JE, Goetz CM, Mclaughlin JL, Suffness M: A blind comparison of simple bench-top bioassays and human tumour cell cytotoxicities as antitumor prescreens. Phytochem Analysis 1991, 2:107-111.

doi:10.1186/1753-6561-8-S4-P31

Cite this article as: Mélo Silva et al:: Evaluation of antibacterial and toxicity activity in vitro of extracts from Tournefortia bicolor S.W (Boraginaceae). BMC Proceedings 2014 8(Suppl 4):P31.

\section{Submit your next manuscript to BioMed Central and take full advantage of:}

- Convenient online submission

- Thorough peer review

- No space constraints or color figure charges

- Immediate publication on acceptance

- Inclusion in PubMed, CAS, Scopus and Google Scholar

- Research which is freely available for redistribution

Submit your manuscript at www.biomedcentral.com/submit
Biomed Central 